\title{
Socrates on Deception, Thievery and Violence: Towards Situational Ethics?
}

\author{
Andrej Kalaš \& František Škvrnda \\ (Comenius University, Bratislava; Economic University in Bratislava)
}

\begin{abstract}
The following paper examines special groups of testimony from the Socratic literature on Socrates' attitude towards unethical forms of behaviour. The first group of texts consists of reflections on the problem of deception and the dilemma of whether it is always right to speak the truth. The next group reflects how various writers of Socratica (Aristophanes, Xenophon, Plato, Antisthenes) interpreted the moral value of thievery. The third group describes Socratic argumentation with regard to violent modes of conduct, such as slavery and beating. It reveals that our extant ancient sources depict Socrates' positive evaluation of certain forms of lying, stealing, swearing and even beating and that Socrates was a moral relativist in a sense, judging in light of the situational context, which constitutes the moral value of action.
\end{abstract}

\section{Keywords}

Socratic question; socratic literature; situational ethics; deception; thievery; violence

The paper was supported by the scientific project VEGA 1/0864/18: Ad Fontes Cynicorum Socraticorum pramene a interpretácia sokratovského kynizmu. 


\section{Introduction}

Socrates has been viewed as an unrivalled champion of virtue and ethics for centuries. His unyielding search for definitions, combined with his unshakeable moral attitude and physical endurance, destined him to be a role model in both modern European and ancient Greek and Roman culture. ${ }^{1}$ Even today, the situation is not all that different. Although there is constant interest in the search for historical Socrates, ${ }^{2}$ not many scholars have argued for historical veracity of Aristophanes' comedy, ${ }^{3}$ and still much less for that of Aristoxenus ${ }^{34}$ or Polycrates'. ${ }^{5}$ After long and exhausted debates, the Socratic question was simply "bracketed" from many recent Socratic studies in favour of Plato' and Xenophon' accounts. ${ }^{6}$

In this paper, we will attempt to take a closer look at Socrates' attitudes towards the moral value of lying, deception, thievery and violence, which remain largely unnoticed by contemporary scholars. We will argue that both the idealized portrayals of Socrates offered by Plato and Xenophon and rather scandalous and denigrating portrayals offered by Aristophanes and in Aristoxenus' and Polycrates' fragments are conveying very similar traits, which might reflect the philosophy and persona of historical Socrates. Our aim is to present, as close as is possible, a coherent depiction of Socrates' practical philosophy, which encompasses evidence from all extant ancient testimonies. We view the method of "comparative exegesis" as the only relevant way to speak about the historical Socrates. ${ }^{7}$ Our approach to Socratic problem regarding the Platonic dialogues is following - although our study generally tries to cite Plato's "early" dialogues, we do not strictly adhere to the position of analytical developmentalism, which draws boundaries between different groups of Platonic dialogues as more or less "Socratic". ${ }^{8}$ Therefore, if some trait of Socrates from the so-called "aporetic" or "elenctic" dialogues emerges in middle class or late dialogues, it is still appropriate for us to interpret it as Socratic. ${ }^{9}$

1 Montuori (1981: pp. 6-18).

2 See Stavru (2013: p. 26).

3 Although Aristophanes' testimony has been treated with little more respect, regarding the Socratic question: Vander Waerdt (1994) "developmentalistic" position maintaning that the Clouds depicts historical Socrates in his "early" intellectual stage is further elaborated and revised by Cerri (2012) and Betegh (2013).

4 See the list of scholars mistreating Aristoxenus' testimony in the study of Huffman (2012: p. 52), which treats Aristoxenus' testimonies about Socrates with much more sobriety.

5 Regarding Polycrates, only exception known to us is the study of Waterfield (2013), which is basically a proposal to solve the Socratic problem through Socrates' political engagement and trial, indicating Polycrates as promising author. Waterfield study remains very sketchy, albeit such theses were already developed in rather exhaustive manner by Chroust (1957) and Montuori (1981).

6 Dorion (2018). See also cautious remarks by Moore (2015: pp. x-xiii). Recent critical evaluation of five main groups of ancient testimonies about Socrates is Porubjak (2018).

7 For classical formulation of the approach of comparative exegesis ("four horses better than one") see Guthrie (1971: p. 9). See also Dorion (2018) and Dorion (2011: pp. 18-21).

8 The standard developmentalistic interpretation of Vlastos, differentiating between two Socrateses in Plato's dialogues, is obsolete and untenable, see especially Stavru \& Rossetti (2010: pp. 36-44).

9 In this manner we treat various dialogues, such as Charmides, Gorgias or Republic, as equally credible with 
The account of Socrates' ethics provided by Plato continues to largely dominate contemporary Socratic scholarship: it is intellectualistic ${ }^{10}$ and rather paradoxical. ${ }^{11}$ According to Irwin, "Socrates commits himself to three main paradoxes: (1) Knowledge of what is good for me is sufficient for action. (2) The virtues that promote my good are the moral virtues. (3) These virtues are sufficient for happiness."12 While these interpretations might be very sophisticated and well argued, they have one disadvantage - while in everyday life we have to face anger, we have to conceal certain things or deal with other problems, Socrates' intellectualism will not help us. We can perhaps look at his brave deeds, how he managed to die, how he acted at trial or during war campaigns, but modern authors scarcely deal with these situational "facts" when writing about Socratic ethics. If we look closer at Socrates' attitudes towards virtues, its definitions and examples, we might find that his intellectualism leads to very problematic practical consequences. It seems, that virtue can be, in specific circumstances, identified with deception, theft or even physical violence.

\section{Deception}

In Platonic dialogues, Socrates frequently debates truthfulness and the commitment to always speaking the truth. ${ }^{13}$ However, his attitudes are not as unequivocal as some modern authors suggest. In Hippias Minor, among other things, lying on purpose is consid-

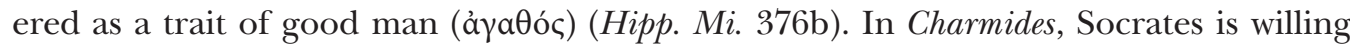
to mislead Charmides, pretending that he possesses a remedy for headaches (Charm. 155b). In the Republic, Socrates remarks that speaking the truth is not the definition of

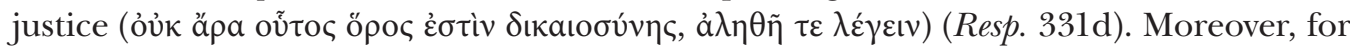

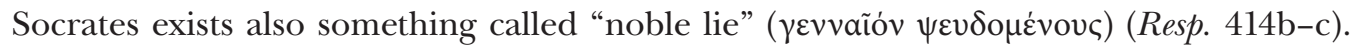
Deception is also considered useful when our friends are acting irrationally - in this case, a liar is compared to a physician spreading honey on the edge of a cup containing bitter medicine (Resp. 382c-d). ${ }^{14}$ In Xenophon we find very similar, if not identical

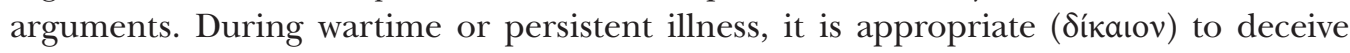
our friends and to refrain from telling the truth (Mem. IV. 2. 13-15). Even Aristophanes' Clouds (Socrates' godesses) were most likely presented on the stage with long noses, symbolizing the patrons of all liars. ${ }^{15}$

the regard to the image of historical Socrates. Even Vlastos was aware of this, see his comment e. g. in Vlastos (1991: p. 163).

10 Brickhouse \& Smith (2013) give account for two dimensions of Socratic intellectualism: motivational and virtue intellectualism.

11 Prior (1991: pp. 74-90) and Irwin (2007: pp. 15-19).

12 Irwin (2007: p. 14).

13 See now classic study by Vlastos (1991: pp. 132-156).

14 On the notion of irony behind Socrates' remarks in the Republic, see Leibowitz (2010: pp. 14-21).

15 Edmunds (1986: p. 222). 
The later testimonies deserve our attention as well. In Libanius' Apologia it is stated that Socrates' prosecutors reproached him for justifying the "moral" aspects of lying. He allegedly approved of the deeds of the mythical king Melanthus, whose rule over Attic territory was a result of his deceiving the Boeotian king Kanthus. Socrates also praised the actions of Themistocles, whose deceptive behaviour saved Athens and the Greeks from the Persians (Apol. Socr. 103-107). ${ }^{16}$ According to Chroust, Xenophon and Libanius (Socrates' most fervent apologists) unintentionally corroborated the charges against him because they conceded that Socrates considered deception good and useful under specific conditions. ${ }^{17}$

From this point of view, it is clear that speaking the truth is dependent on the actual circumstances and cannot be taken as a universal principle of righteous conduct. On the question of the ethical consequences of speaking the truth, we can say that Socrates was at least flirting with relativism, not only because he is just playing some "dialectical tricks" on sophists ${ }^{18}$ but because of the moral value of lies themselves.

However, it is important to distinguish the overall context of this Socrates' debates on speaking the truth. Even in Homer the Odysseus lies to the menacing cyclops Polyphemus only to save his own life. He also uses deception as a means of getting rid of Penelope's arrogant suitors. ${ }^{19}$ In the case of Socrates' approval of deception, things are very similar - deceptive behaviour can be justified only by noble reason, which is always goodness - lying to save one's life, the polis, the whole nation, or to restore health. Is it possible that Socrates considers the function of lies in this archaic, Homeric context?

The problem arises when we turn our attention to Plato's Apology, where Socrates is

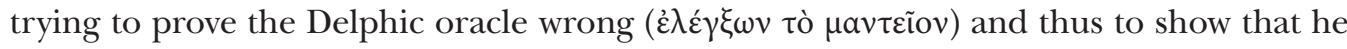
is not the wisest of all men (Apol. 21b-21c). Why does Socrates mistrust the god, who "certainly cannot be lying, for that is not possible for him"? It seems that there is only one viable explanation of this paradox: Socrates understands the moral qualities of gods in the traditional sense. Ever since Homer and Hesiod, the gods have had an ambiguous nature. In Hesiod, they could "tell manifold lies" and "give truthful accounts" (à $\lambda \eta \theta \dot{\varepsilon} \alpha$

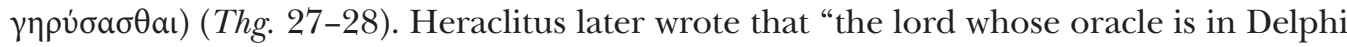
neither declares nor conceals, but gives a sign" (fr. XXXIII Kahn). ${ }^{20}$ Therefore, gods stand above the concepts of "truth" and "lie", which are common to mortals. Socrates could calmly accuse the Delphic oracle of "lying" because such a divine "lie" is in fact noble - a manifestation of the gods' care for mortals. By communicating such enigmatic divine "signs", which might easily be misunderstood by human reasoning as deceptive, gods provide us with something good - something that makes us better, more judicious and cunning, more conscientious. If Socrates obeyed the gods wherever they led him, it

16 Chroust (1957: p. 92) indicates that Libanius is reproducing allegations from Polycrates' Accusation of Socrates.

17 Chroust (1957: p. 92).

18 See e. g. Friedländer (1964: p. 181); Kahn (1983: p. 93).

19 See Walcot (1977). As Prior remarks, "Odysseus' practical wisdom does not include as a matter of course the moral virtue of truthfulness” (Prior 1991: p. 19).

20 Transl. Kahn (1979: p. 43). 
is very probable that he also considered it important to distinguish between situations in which it is good to tell others the truth and those in which doing so is counterproductive. His deception of Charmides is exemplary: if it had not been in the service of Charmides' own good, he would not have pretended to possess a remedy for headaches. Socrates is ironic and approves deceptive behaviour to others because this type of conduct and cunning helps them, among other things, to know themselves better, just as Apollo helped Socrates when he pronounced him the wisest of all men.

\section{Thievery}

Socrates' peculiar understanding of deception and truthfulness was probably not the sole reason why he was accused of corrupting the youth. In Libanius, we find another hint which may lie behind it - Socrates allegedly praised Odysseus for stealing the Trojan palladium (Apol. Socr. 105.4). Although Libanius does not say anything specific about why Socrates approved of Odysseus' behaviour, this is easily explained. The ultimate purpose of stealing the palladium was to win the Trojan war; according to the tradition preserved in the Little Iliad, Troy could not be defeated while the palladium remained in the city (Proclus, Chrest. 228). Socrates' praise of the theft, however, has unexpected parallels in his practical-philosophical way of life.

The comic poets Eupolis, Aristophanes and Ameipsias portrayed Socrates as a petty thief. In their depictions, he stole amphorae of wine, food from altars in sacred precincts, and even old, worn-out coats. ${ }^{21} \mathrm{~A}$ favourite target of these comic poets was another petty thief, Chaerephon, one of Socrates' closest companions. ${ }^{22}$ Another person from Socrates' circle who was infamous for his thievish nature was the poverty-stricken Aeschines of Sphettus. Aeschines was rebuked for thieving even by his fellow socratic companion, Aristippus of Cyrene (DL II 62). According to the rhetorician Lysias, Aeschines borrowed money from a client to run a perfume shop but never paid off his debt. Apart from this episode, Lysias purportedly also mentioned Aeschines' scandalous marriage to a wealthy old widow (Athenaeus 611d-612f). Lysias was on friendly terms with Socrates himself, so it is quite difficult to view his testimony as a sign of animosity, especially since he reflects Aeschines' affiliation with Socrates in a positive manner.

These reports might be read in the context of a rare piece of information from Aristoxenus' Life of Socrates, where it is stated that Socrates used to make his living as a money handler ( $\chi \rho \eta \mu \alpha \tau i \sigma \alpha \sigma \theta \alpha \mathrm{l})$, gathering and then disbursing small amounts of currency

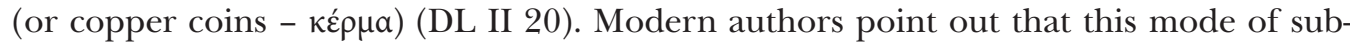
sistence need not necessarily be labelled "deceptive". ${ }^{23}$ The same may be said of Lysias' testimony - we do not know whether Aeschines refused to repay his debt to his creditor

21 See Eupolis (fr. 361 Kock) and Aristophanes (Nub. 176-179; see also verses 910-911 for the word

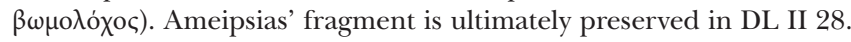

22 Aristophanes (fr. 291 and 539 Kock). On Chaerephon as Socrates' closest companion, see Moore (2013). Aristophanes also mentions the thief Hyperbolus as another of Socrates' disciples (Nub. 1065).

23 Huffman (2012: pp. 261-263). 
because that creditor was immoral or licentious (or whether Aeschines really loved his older wife).

Dismissal of Socrates' thievish nature is rather difficult because its traces are also embedded in the texts of Plato and Xenophon. In the Republic, it is said that the guardians ought to live on public expenses because of their hard work (Resp. 416d-e). Of course, Plato's guardians do not need much - only basic clothes and modest food. These are exactly the types of things that were ridiculed by the comic authors as the objects of Socrates' petty theft. Xenophon strives to excuse Socrates from this type of criminal behaviour, but he does not sound very convincing. Socrates allegedly did not engage in

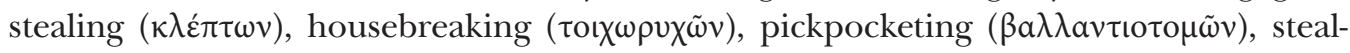

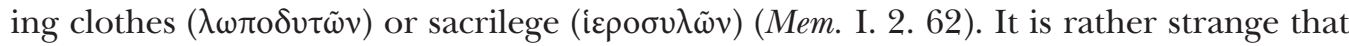
Xenophon lumps small misdeeds together with capital crimes. This probably did not reflect Athenian law at the time, which must have distinguished between petty misdeeds such as stealing an old, tattered cloak or small portions of food in the temple (which was anyway meant for poor people) and serious crimes such as the organized theft of gilded robes or precious temple treasures.

In addition, there are passages in Xenophon where Socrates defends stealing, looting and other forms of theft, arguing that these actions are excusable when directed not only at our enemies but also at our friends (Mem. IV. 2. 14-17). Socrates calls this not a "crime" but a "benefaction". In the same manner, Plato's Socrates designates stealing a weapon from a friend who has gone insane as a benefaction (Resp. 331c). Last but not least, we should not forget this Socrates' witty syllogism, which is sometimes ascribed to Diogenes of Sinope: a philosopher is a friend of gods, and since everything is common to friends, all things belonging to gods also belong to the philosopher (DL VI 37, 72).

In the Socratic literature, the dividing line between "thievery" and "benefaction" is blurred in much the same way that deception is. When dealing with a madman, for example, it would be good to steal his weapon; the weapon is no longer useful in this context and its possession may even be dangerous. In other cases, thievery can be branded under specific conditions as repayment for the hard work of the philosopher, which may not be recognized by those who benefit from it as "work" or benefaction at all. ${ }^{24}$ Laymen simply do not understand what is good or bad, desirable or undesirable. This is a problem of philosophical vocabulary - Plato and Xenophon could excuse Socrates' behaviour because it was for the sake of a higher good and thus did not count as thievery, a term that evokes a corrupt form of behaviour.

\section{Violence}

In the lost dialogue by Phaedo of Elis, Zopyrus, ${ }^{25}$ Socrates and his friends met with the Persian master of physiognomy, Zopyrus. Zopyrus surmised from Socrates' bodily and

24 See Socrates' complaints in Plato's Apology (37e).

25 Boys-Stones (2007: p. 23) notes that this Phaedo's fragment is not included in the collection by Giannantoni. Phaedo's authorship is thus slightly problematic, but, according to this author, still probable. 
facial features that he was a very intemperate and excessive person. When Socrates' friends began to mock and ridicule Zopyrus for his erroneous assessment, Socrates hushed them and told Zopyrus that he was right. Socrates added, however, that he had become a better person through much effort.

Based on Aristoxenus' testimony, we can conclude that Socrates never completely repudiated his fiery nature, even later in life. Aristoxenus wrote that Socrates was "li-

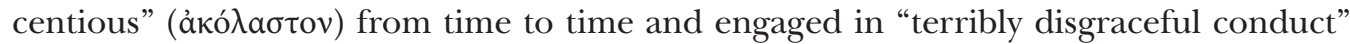

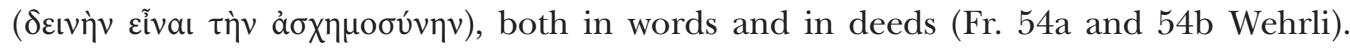
Aristoxenus further mentions that according to Spintharus - one of the Socrates' fellows - despite his choleric nature, Socrates had never performed an unrighteous act

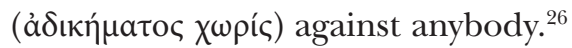

Both Plato and Xenophon testify that Socrates was prone to certain forms of violence. In Hippias Maior, we encounter Socrates' mysterious doppelgänger. Socrates is afraid that if he accepts Hippias' claim that to be beautiful is to be "rich and healthy and honoured by the Greeks, to reach old age, and after providing a beautiful funeral for his deceased parents, to be beautifully and splendidly buried by his own offspring" ([Pl.], Hipp. Ma. 291d-e), ${ }^{27}$ his mysterious friend will not only ridicule him for holding such a definition

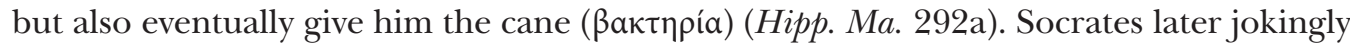
remarks that his mysterious, aggressive friend is actually he himself (Hipp. Ma. 298c). For Plato's Socrates, there exists only one greater evil than being unjust: "to do wrong and not pay the penalty" (Gorg. 479d). ${ }^{28}$ In Plato's Apology it is stated very clearly: nothing is bad for a good man (Apol. 41c-d). While modern scholars read this last passage as evidence that for Socrates virtue alone was sufficient for happiness, ${ }^{29}$ we read it as evidence that good man can do anything at his will.

Xenophon writes that the prosecutors reproached Socrates for his public recitation of the following words from Homer's Ilias: "Whomsoever he met that was a chieftain or man of note, to his side would he come and with gentle words seek to restrain him, saying: 'Good Sir, it beseems not to seek to affright thee as if thou were a coward, but do thou thyself sit thee down, and make the rest of thy people to sit' ... but whatsoever man of the people he saw, and found brawling, him would he smite with his staff; and chide with words, saying: 'Fellow, sit thou still, and hearken to the words of others that are better men than thou; whereas thou art unwarlike and a weakling, neither to be counted in war nor in counsel'." (Xen., Mem. I. 2. 58 = Homer, Il. II. 188-191 and 198-202). ${ }^{30}$

According to Socrates' prosecutors, he read these verses as evidence that beating lowborn (democratic) people was natural and right. It is interesting that Xenophon does not even try to refute this accusation on the whole. He only adds that Socrates considered it

26 Cf. Suidas, s.v. $\Sigma \omega \kappa$ кátпৎ 829. 6. The information in Diogenes Laertius about Socrates' irascible but not unrighteous behaviour illustrates Aristoxenus' words and may ultimately come from his Life of Socrates (see DL II 21).

27 Transl. Fowler (1926: p. 375).

28 Italics by author. Transl. Lamb (1925: p. 373).

29 Irwin (2007: p. 28).

30 Transl. Murray (1928: p. 65). 


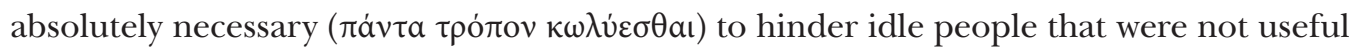
to society or to other individuals (Mem. I. 2. 59). In truth, Xenophon stresses Socrates' philanthropy while reporting that he was keen to debate with anyone free of charge. But how this "amiable" side of Socrates may have looked to others can be gleaned from many passages in Plato's and Xenophon's works, in which Socrates is associated with irony and ridicule, reproaching others for their ignorance and persuading them that they ought to live like slaves rather than free men if they are useless due to the lack of wisdom and moderation. It is telling that in the one and only passage from Memorabilia where Socrates speaks directly with Xenophon, he addresses him as an "idiot" ( $\tilde{\omega} \mu \tilde{\omega} \rho \varepsilon)($ Mem. I. 3. 13). This might be normal Socratic behaviour: when Critias was unable to control himself in matters of love, Socrates publicly declared that he was "swinish" (Mem. I. 2. 30).

Neither comic poet fails to notice Socrates' positive attitude towards violence. Socrates' pupils - the good and the bad arguments - hurl countless obscenities at each other (Aristoph., Nub. 890-945). One of the things that Pheidippides learns from Socrates is how to justify beating his own father: it is righteous to beat somebody if the attacker is

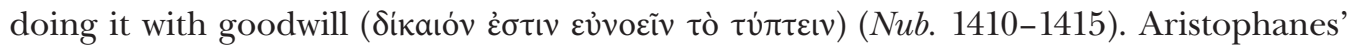
Socrates also considers beating appropriate in cases where a person is ignoring custom and tradition, for such a one disparages the Muses (Nub. 972). Yet musical activity is a form of philosophy, according to Plato's Socrates. Is Aristophanes pointing to Socrates' belief that those who are ignorant of philosophy deserve a beating?

Reproaching others for their moral flaws and lack of virtue is a typical feature of the Cynical way of life and its important practice of speaking the truth, parrhesia $\cdot{ }^{31}$ It is very probable that Cynical practical philosophy also included violence as an important way

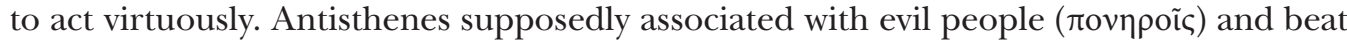
his own pupils (DL VI 4, 6, 21). Diogenes devoted a boxer to the temple of Asclepius to beat the people worshipping there, and he himself occasionally engaged in fights with corrupt and base people, such as Meidias (DL VI 38, 41-42, 66).

\section{Conclusion}

This picture of the lying, stealing, raging Socrates seems to be at odds with high praise of modern readers and philosophers. But on a closer look, this picture perfectly fits into Socrates' ethics. Being moderate and prudent does not necessarily preclude acting in righteous anger or using physical violence in certain situations. Lying and stealing, or causing physical wounds to other people, are not reducible to "wrong" and "evil" in all cases. More important than telling the truth or staying sober in every situation is the ability to recognize situations in which deception and anger are desirable modes of conduct.

For Socrates, the good was identical to the useful. ${ }^{32}$ But again, what counts as useful for me, cannot be stated universally; it can be recognised only in specific situations. We

31 This theme is treated in detail by Montiglio (2011: pp. 20-37), who notes that in Antisthenes' works “Odysseus' тодитроті́a ... is not unethical" (p. 34).

32 This is a classic Socratic claim; see e.g. Guthrie (1971: pp. 142-147). 
need to understand Socrates' approval of deception, thievery and violence in this very situational context, and it may be precisely this feature that distinguishes the historical Socrates from his idealized depictions. Socrates' ethics could be equally defined "situational" as well as "intellectualistic". It is this side of his ethics that is dangerously close to sophists and their moral relativity and that could be the real cause for his prosecution on the behalf of corrupting the youth. In the eyes of Athenian public he was just another clever twister making the weaker argument stronger.

Despite his positive attitude toward morally corrupted modes of conduct, Socrates does not necessarily need to be labelled as moral relativist. Aristophanes, Aristoxenus, Plato, and Xenophon all agree on one point: Socrates and his disciples viewed physical violence as justified only when relied on as a means to obtain a higher good, and only when devoid of injustice. People who are inclined to good advice and who are ready to voluntarily eradicate their vices are to be admonished by calm words alone, whereas those who do not harken to good advice must be rebuked more harshly, ultima ratione, by physical violence, punishment or deception.

Somebody may object that treating the words attributed to Socrates and his deeds as equally valid, is wrong, that examples of violent behaviour of any person cannot be translated into approval of violence, since human beings are not driven by ethical deliberations only, but also by numerous other factors, which can be later regretted. However, in our extant sources Socrates' does not regret nothing, he never takes back his ideas or attitude towards deception, thievery or violence. He appears to be fully convinced about his inferences, and it seems that his words are in perfect match with his deeds.

We have tried to show that the situational character of Socrates' ethics is well embedded in all ancient sources and provides us with a sound partial explanation for why he was prosecuted. Yet our traditional image of Socrates as a moral philosopher remains preserved in one important respect - in his philosophical pursuit of goodness. This end, however, may be achieved by any means necessary - including deception, violence and thievery.

\section{Bibliography}

\section{Primary Sources}

Adler, A. (Ed.). (1928-1935). Suidae Lexicon. Leipzig: Teubner.

Allen, T. W. (Ed.). (1931). Homeri Ilias (Vol. I). Oxford: Clarendon Press.

Burnet, J. (Ed.). (1900-1907). Platonis Opera. Oxford: Clarendon Press.

Dover, K. J. (Ed.). (1968). Aristophanes: Nubes. Oxford: Clarendon Press.

Kaibel, G. (Ed.). (1890). Athenaei Naucratitae deipnosophistarum libri xv (Vol. III). Leipzig: Teubner.

Lamb, W. R. M. (Transl.). (1925). Plato: Lysis, Symposium, Gorgias (Loeb Classical Library, 166). Cambridge, MA: Harvard University Press.

Long, H. S. (Ed.). (1964). Diogenis Laertii vitae philosophorum. Oxford: Clarendon Press. Marchant, E. C. (Ed.). (1921). Xenophontis opera omnia (Vol. II). Oxford: Clarendon Press. 


\section{Secondary Sources}

Betegh, G. (2013). Socrate et Archélaos dans les Nuées. In A. Laks \& R. Saetta Cottone (Eds.), Comédie et Philosophie: Socrate et les "présocratiques » dans les Nuées d'Aristophane (pp. 87-106). Paris: Editions Rue d'Ulm.

Boys-Stones, G. (2007). Physiognomy and Ancient Psychological Theory. In S. Swain (Ed.), Seeing the Face, Seeing the Soul: Polemon's Physiognomy from Classical Antiquity to Medieval Islam (pp. 19-124). Oxford: Oxford University Press.

Brickhouse, T. C., \& Smith, N. D. (2013). Socratic Moral Psychology. In J. Bussanich, \& N. D. Smith (Eds.), The Bloomsbury Companion to Socrates (pp. 185-209). London: Bloomsbury.

Cerri, G. (2012). Le Nuvole di Aristofane e la realtà storica di Socrate. In F. Perusino \& M. Colantonio (Eds.), La commedia greca e la storia (pp. 151-194). Pisa: EDIZIONI ETS.

Chroust, A.-H. (1957). Socrates. The Man and the Myth. The Two Socratic Apologies of Xenophon. London: Routledge \& Kegan Paul.

Dorion, L.-A. (2011). The Rise and Fall of the Socratic Problem. In Morrison, D. (Ed.), The Cambridge Companion to Socrates (pp. 1-23). New York: Cambridge University Press.

Dorion, L.-A. (2018). Comparative Exegesis and the Socratic Problem. In G. Danzig, D. Johnson, D. Morrison (Eds.), Plato and Xenophon. Comparative Studies (pp. 55-70). Leiden: Brill.

Edmunds, L. (1986). Aristophanes' Socrates. Proceedings of the Boston Area Colloquium in Ancient Philosophy, 1, 209-230.

Fowler, H. N. (1926). Cratylus. Parmenides. Greater Hippias. Lesser Hippias. London: Harvard University Press.

Friedländer, P. (1964). Plato: The Dialogues. First Period (Transl. P. Meyerhoff). London: Pantheon Books.

Guthrie, W. K. C. (1971). Socrates. Cambridge: Cambridge University Press.

Huffman, C. A. (2012). Aristoxenus' Life of Socrates. In C. A. Huffman (Ed.), Aristoxenus of Tarentum: Discussion (pp. 251-281). New Brunswick: Transaction Publishers.

Irwin, T. (2007). The Development of Ethics. A Historical and Critical Study. Volume I: From Socrates to the Reformation. New York: Oxford University Press.

Kahn, Ch. (1979). The Art and Thought of Heraclitus. Cambridge: Cambridge University Press.

Kahn, Ch. (1983). Drama and Dialectic in Plato's Gorgias. Oxford Studies in Classical Philosophy, 1, $75-122$.

Kock, T. (1880). Comicorum Atticorum Fragmenta. Leipzig: B. G. Teubner.

Leibowitz, D. M. (2010). The Ironic Defense of Socrates. Cambridge: Cambridge University Press.

Montiglio, S. (2011). From Villain to Hero - Odysseus in the Ancient Thought. Ann Arbor: The University of Michigan Press.

Montuori, M. (1981). Socrates. Physiology of a Myth. Amsterdam: J. C. Gieben.

Moore, Ch. (2013). Chaerephon the Socratic. Phoenix, 67(3-4), 284-300.

Moore, Ch. (2015). Socrates and Self-Knowledge. Cambridge: Cambridge University Press.

Murray, A. T. (1928). The Iliad. London: Harvard University Press.

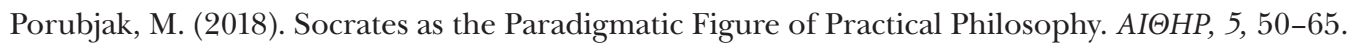

Prior, W. J. (1991). Virtue and Knowledge. An Introduction to Ancient Greek Ethics. New York: Routledge. 
Stavru, A. (2013). The Present State of Socratic Studies: An Overview. In F. de Luise, \& A. Stavru

(Eds.), Socratica III: Studies on Socrates, the Socratics, and the Ancient Socratic Literature (pp. 11-26).

Sankt Augustin: Academia Verlag.

Stavru, A. \& Rossetti, L. (2010). Introduction. In: Stavru, A., \& Rossetti, L.

(Eds.), Socratica 2008. Studies in Ancient Socratic Literature (pp. 11-55). Bari: Levante.

Vlastos, G. (1991). Socrates. Ironist and Moral Philosopher. Cambridge: Cambridge University Press.

Walcot, P. (1977). Odysseus and the Art of Lying. Ancient Society, 8, 1-19.

Waterfield, R. (2013). The Quest for the Historical Socrates. In J. Bussanich, \& N. D. Smith (Eds.),

The Bloomsbury Companion to Socrates (pp. 1-19). London: Bloomsbury.

Wehrli, F. (1945). Die Schule des Aristoteles. Aristoxenos. Basle: Benno Schwabe \& Co.

Doc. Mgr. Andrej Kalaš, PhD. / andrej.kalas@uniba.sk

Department of Philosophy and History of Philosophy

Comenius University, Philosophical Faculty

Šafárikovo nám. 6, 81499 Bratislava, Slovak Republic

Mgr. František Škvrnda, PhD. / frantisek.skvrnda2@euba.sk

Department of International Political Relations

Economic University in Bratislava, Faculty of International Relations

Dolnozemská cesta 1, 85235 Bratislava, Slovak Republic

Toto dílo Ize užít v souladu s licenčními podmínkami Creative Commons BY-SA 4.0 International (https://creativecommons.org/licenses/by-sa/4.0/legalcode). Uvedené se nevztahuje na díla či prvky (např. obrazovou či fotografickou dokumentaci), které jsou v díle užity na základě smluvní licence nebo výjimky či omezení příslušných práv. 
